\title{
Preoperative CYP2D6 metabolism-dependent $\beta$-blocker use and mortality after coronary artery bypass grafting surgery
}

\author{
Miklos D. Kertai, MD, PhD, ${ }^{\text {a }}$ Stephen A. Esper, MD, MBA, ${ }^{b}$ Igor Akushevich, $\mathrm{PhD},{ }^{\mathrm{c}}$ Deepak Voora, MD, ${ }^{\mathrm{d}}$ \\ Geoffrey S. Ginsburg, MD, PhD, ${ }^{\mathrm{d}}$ Mark Stafford-Smith, MD, ${ }^{\mathrm{a}}$ Katherine Grichnik, MD, ${ }^{\mathrm{a}}$ \\ Mark F. Newman, MD, ${ }^{\mathrm{a}}$ Manuel L. Fontes, MD, ${ }^{\mathrm{a}}$ Peter Smith, MD, ${ }^{\mathrm{e}}$ Mihai V. Podgoreanu, MD, ${ }^{\mathrm{a}}$ and \\ Joseph P. Mathew, MD, MHSc, ${ }^{a}$ Cardiothoracic Anesthesia Research Endeavors (CARE) Group
}

\begin{abstract}
Objective: Recently, the role of $\beta$-blockers (BBs) in reducing perioperative mortality has been challenged. The conflicting results might have resulted from the extent of BB metabolism by the cytochrome P-450 (CYP2D6) isoenzyme. The purpose of the present study was to assess the association between the preoperative use of BBs dependent on metabolism of the CYP2D6 isoenzyme with operative mortality after coronary artery bypass grafting surgery.

Methods: We performed a retrospective study of 5248 patients who had undergone coronary bypass grafting surgery from January 1, 2001 to November 30, 2009 at Duke University Medical Center. The cohorts were defined by the preoperative use of BBs and BB type (non-CYP2D6_BBs, CYP2D6_BBs, or no BBs). Operative mortality was analyzed using inverse probability-weighted estimators with propensity score adjustment.
\end{abstract}

\begin{abstract}
Results: Of the 5248 patients, 14\% received non-CYP2D6_BBs, 43\%,CYP2D6_BBs, and 43\%, no BBs. The incidence of operative mortality was $0.8 \%, 2.1 \%$, and $3.7 \%$ in the non-CYP2D6_BB, CYP2D6_BB, and no BB groups, respectively. Multivariable inverse probability-weighted-adjusted analyses showed that nonCYP2D6_BBs were associated with a lower incidence of operative mortality (odds ratio, $0.33 ; 95 \%$ confidence interval, $0.13-0.83 ; P=.02$ ) compared with no BB use and a trend toward lower operative mortality (odds ratio, 0.44; $95 \%$ confidence interval, 0.16-1.07; $P=.06$ ) compared with CYP2D6_BBs. No significant decrease occurred in the risk of operative mortality between the CYP2D6_BB and no BB groups (odds ratio, $0.85 ; 95 \%$ confidence interval, $0.54-1.34 ; P=.48)$.
\end{abstract}

Conclusions: Among these patients, preoperative non-CYP2D6_BB use, but not CYP2D6_BB use, was associated with a decreased risk of operative mortality. (J Thorac Cardiovasc Surg 2014;147:1368-75)

Supplemental material is available online.

From the Division of Cardiothoracic Anesthesiology and Critical Care, ${ }^{\mathrm{a}}$ Department of Anesthesiology, Duke University Medical Center, Durham, NC; Division of Cardiovascular and Thoracic Anesthesiology, ${ }^{\mathrm{b}}$ Department of Anesthesiology, University of Pittsburgh Medical Center, Pittsburgh, Pa; Center for Population Health and Aging, ${ }^{c}$ Duke University Medical Center, Durham, NC; Duke Institute for Genome Science and Policy, ${ }^{\mathrm{d}}$ Duke University Medical Center, Durham, NC; and Division of Cardiovascular and Thoracic Surgery, ${ }^{\mathrm{e}}$ Department of Surgery, Duke University Medical Center, Durham, NC.

Support for the present study was provided solely from institutional and/or departmental sources.

Disclosures: Dr Smith reports consulting fees from CSL Behring. Dr Newman reports grant support from Merck. Dr Ginsburg reports consulting fees from Pappas ventures, TheHeart.org, Medscape, and Universal Oncology as well as equity ownership in CardinalDx and Universal Oncolgy. All other authors have nothing to disclose with regard to commercial support.

Drs Kertai and Esper and Podgoreanu and Mathew contributed equally to this work and should be considered co-first and co-senior authors, respectively.

The members of the CARE Group are listed in the Appendix.

Received for publication June 19, 2013; revisions received Sept 14, 2013; accepted for publication Sept 30, 2013; available ahead of print Nov 25, 2013.

Address for reprints: Miklos D. Kertai, MD, PhD, Department of Anesthesiology, Duke University Medical Center, 2301 Erwin Rd, 5693 HAFS Bldg, DUMC 3094, Durham, NC 27710 (E-mail: miklos.kertai@ duke.edu).

$0022-5223 / \$ 36.00$

Copyright $(\odot) 2014$ by The American Association for Thoracic Surgery

http://dx.doi.org/10.1016/j.jtcvs.2013.09.067
Cardiovascular morbidity and mortality are common and costly complications in patients undergoing cardiac and noncardiac surgery. ${ }^{1}$ Surgical coronary revascularization has been associated with a mortality rate of $2.3 \%$ and a perioperative myocardial infarction rate of $\leq 17 \% .{ }^{1,2}$ It is widely believed that heightened sympathetic nervous system activity in response to surgical stress plays a fundamental role in the development of perioperative cardiac complications and that pharmacologic attenuation of this response with $\beta$-blockers (BBs) will lead to improved patient outcomes. ${ }^{3,4}$

The benefits of BB therapy have recently been questioned by reports of side effects such as hypotension and bradycardia, which have been associated with a significantly increased incidence of perioperative death and nonfatal stroke in patients undergoing noncardiac surgery. ${ }^{4}$ Moreover, accounting for demographic and clinical characteristics, the efficacy and toxicity of BBs in the treatment of hypertension, ${ }^{5}$ coronary artery disease, ${ }^{6}$ and heart failure have varied significantly, even among nonsurgical patient populations.

A number of genetic variants with a substantial influence on the efficacy and safety of BBs have been characterized. including inherited differences in the metabolism of BBs. One of the most extensively studied and characterized examples of pharmacogenetic variation is the cytochrome 


$$
\begin{array}{ll}
\text { Abbreviations and Acronyms } \\
\text { BB } & =\beta \text {-blocker } \\
\text { CABG } & =\text { coronary artery bypass grafting } \\
\text { CI } & =\text { confidence interval } \\
\text { EuroSCORE }= & \text { European System for Cardiac } \\
& \text { Operative Risk Evaluation score } \\
\text { IPW } & =\text { inverse probability weighting } \\
\text { OR } & =\text { odds ratio } \\
\text { PM } & =\text { poor metabolizer }
\end{array}
$$

P-4502D6 isoenzyme or CYP2D6, which is involved in the hepatic elimination of several drugs, including analgesics, anti-arrhythmics, antidepressants, and most of the lipophilic BBs (eg, metoprolol, propranolol, carvedilol, and labetalol). This is in contrast to hydrophilic BBs, such as atenolol and sotalol, which are eliminated largely unchanged by glomerular filtration and, thus, independent of CYP2D6 activity. Metoprolol is the most dependent on this enzyme, with $70 \%$ to $80 \%$ of its biotransformation directed through this pathway. ${ }^{7}$ Clinical studies have observed that subjects characterized as being a CYP2D6 poor metabolizer (PM) had a significantly greater risk of bradycardia, ${ }^{5,8}$ hypotension, ${ }^{5,8}$ and other adverse effects during metoprolol treatment. ${ }^{9}$

In addition, BBs have a broad therapeutic index, and the effect of PM status on the therapeutic safety of BBs metabolized by way of CYP2D6 might become clinically apparent only in patients at an increased risk of $\beta$-blockade, such as patients with poor left ventricular function. ${ }^{3,9}$ Although there is a noticeable lack of studies examining the contribution of CYP2D6 genetic variations on the efficacy and safety of BBs in the perioperative setting is noticeable, Badgett and colleagues ${ }^{10}$ conducted a meta-analysis of existing trials of perioperative BB use in the setting of noncardiac surgery and found that increased mortality was confined to trials that had used BBs that were dependent on the CYP2D6 metabolism. This was recently re-emphasized in a large retrospective cohort analysis of patients undergoing major noncardiac surgery. ${ }^{11}$ They identified stronger associations with perioperative mortality among patients treated with metoprolol rather than with atenolol. ${ }^{11}$ To date, however, no randomized or observational studies have evaluated the association between preoperative use of BBs dependent on CYP2D6 metabolism and operative mortality after cardiac surgery. Therefore, using a large observational cohort of patients who had undergone CABG surgery, we sought to determine whether the operative mortality rates differed for patients treated with BBs dependent on the CYP2D6 metabolism (CYP2D6_BBs), patients treated BBs that were independent of CYP2D6 metabolism (non-CYP2D6_BBs), and patients without BB use.

\section{METHODS}

\section{Study Population}

For the present retrospective observational study, we evaluated 5340 patients who had undergone off-pump or on pump CABG from January 1, 2001 to November 30, 2009 at Duke University Medical Center (Durham, NC).

\section{Data Collection}

After obtaining approval from the institutional review board, the perioperative variables were collected from the Duke University Medical Center databases, including the Automated Anesthesia Recordkeeping Database (intraoperative BB and other cardiovascular drug use), Cardiac Surgery Quality Assurance Database, Duke Databank for Cardiovascular Diseases, and the patients' electronic medical records. Two independent investigators (M.D.K. and S.A.E.) ascertained the data quality by performing regular crosschecks for completeness and inconsistencies between the data set assembled and the medical records.

\section{Clinical Risk Factor Definitions}

The potential clinical determinants of all-cause mortality collected for the present study included patient characteristics, preoperative and intraoperative medication use, preoperative laboratory values (serum creatinine), the European System for Cardiac Operative Risk Evaluation score (EuroSCORE; definitions of the EuroSCORE are provided in Table E1), ${ }^{12}$ and the cardiopulmonary bypass and aortic crossclamping times. The intraoperative use and type of BBs, inotropes, vasopressors, and vasodilators were also recorded.

\section{Cardiac Medication Use}

For patients with acute coronary syndromes, cardiac medication use was noted on arrival at the hospital. For electively treated patients, this medication information was obtained routinely during the outpatient clinic visit before hospital admission for cardiac surgery. A history of cardiac medication use ( $\alpha$-receptor blockers, angiotensin-converting enzyme inhibitors, angiotensin receptor blockers, aspirin, BBs, calcium channel blockers, clopidogrel, diuretics, nitrate, statins, and warfarin) was established if the patient had taken the medicine within 24 hours before cardiac surgery. According to institutional practice, the patients continued to take their medication on the evening before surgery and, absent contraindications, resumed oral medications on postoperative day 1 . Aspirin was not discontinued, but clopidogrel was discontinued for $\geq 7$ days before surgery. Warfarin was discontinued 4 days preoperatively and "bridged" with intravenous heparin infusion.

The treatment groups in the present study were determined by preoperative BB use and the BB type. Patients with a history of preoperative use of carvedilol $(\mathrm{n}=254)$, labetalol $(\mathrm{n}=25)$, metoprolol $(\mathrm{n}=1936)$, nebivolol $(n=6)$, or propranolol $(n=25)$ were assigned to the CYP2D6_BB group. Patients with a history of preoperative use of acebutolol $(\mathrm{n}=5)$, atenolol $(n=695)$, bisoprolol $(n=24)$, nadolol $(n=12)$, or sotalolol $(n=20)$ were assigned to the non-CYP2D6_BB group. Patients with no history of preoperative $\mathrm{BB}$ use were assigned to the no BB group. Those who had received both types of BBs preoperatively-with and without CYP2D6dependent metabolism-were excluded from the present study. Of the initial 5340 patients evaluated, 5248 had information available on the preoperative BB type used, and their data were included in our analyses.

\section{Outcome Classification}

The outcome chosen for the present study was all-cause operative mortality, defined as deaths occurring during the same hospitalization as surgery, regardless of timing, or within 30 days of surgery, regardless of venue, unless the cause of death was clearly unrelated to the operation, such as trauma. ${ }^{3}$ For patients who died at Duke University Medical Center, the hospital records and autopsy results, when available, were retrieved and 
reviewed. In addition, the National Death Index (available at: http://www. cdc.gov/nchs/ndi.htm) was accessed to ascertain the vital status of patients discharged alive within 30 days of surgery.

\section{Statistical Analysis}

The baseline characteristics are presented as the mean \pm standard deviation for continuous variables and as percentages and frequencies for categorical variables. Differences between groups with a specific treatment were assessed using the $t$ test, analysis of variance, Kruskal-Wallis test, or chi-square test, as appropriate.

Because the treatment assignment to preoperative $\mathrm{BB}$ administration was not random, a propensity score-based approach involving inverse probability weighting (IPW) was used to control for treatment selection (see Supplemental methods). The effects of specific variables on mortality (eg, non-CYP2D6_BBs or CYP2D6_BBs compared with no BBs, or a difference between the 2 groups of BBs) were subsequently studied in multivariable logistic regression analyses with and without weights and, thus, providing results adjusted for treatment selection.

The discriminatory power of the final multivariable model of operative mortality was quantified by the c-index, corresponding to the area under the receiver operating characteristics curve, ranging from 0.5 (performance at chance) to 1.0 (optimal performance; see Supplemental Methods). The model fit of the final multivariable model was further assessed using the Hosmer-Lemeshow goodness-of-fit test. Odds ratios (ORs) and the corresponding $95 \%$ confidence intervals (CIs) are reported. The analyses were performed using Statistical Analysis Systems, version 9.2 (SAS Institute, Inc, Cary, NC); $P<.05$ was considered significant.

\section{RESULTS}

The clinical characteristics of the 3 treatment groups in the study population are listed in Table 1 . Of the 5248 patients, 43\% had received a CYP2D6_BB, 14\%, a non-CYP2D6_BB, and 43\%, no BBs preoperatively. Of the 5248 patients, 137 died perioperatively. Of these, 74 were cardiac deaths. Death was attributed to multiorgan failure in 27 patients, stroke in 11 patients, and respiratory failure in 9 patients. In the remaining 16 patients, the cause of death was bleeding, intestinal necrosis, or vascular thrombosis.

The data listed in Table 1 revealed statistically significant differences among the groups for many clinical characteristics, including age, race, medical history, concomitant comorbidities, previous medications, and intraoperative characteristics. After propensity score adjustment, no significant imbalance was observed in the patient characteristics among the groups (Table E2).

Several preoperative and intraoperative variables were found in the univariable analysis to be significantly associated with an increased risk of operative mortality. However, the use of aspirin, $\alpha$-receptor blockers, angiotensin-converting enzyme inhibitors, statins, and intraoperative esmolol and metoprolol were associated with significant reductions in mortality risk (Table 2). In addition, patients receiving a non-CYP2D6_BB or a CYP2D6_BB preoperatively had a lower incidence of operative mortality than the patients who did not receive a BB preoperatively $(0.8 \%$ and $2.1 \%$ vs $3.7 \%$, respectively; $P<.0001)$.
TABLE 1. Baseline characteristics of study population $(n=5248)$

\begin{tabular}{|c|c|c|c|c|}
\hline \multirow[b]{2}{*}{ Characteristic } & \multicolumn{3}{|c|}{ BBs } & \multirow[b]{2}{*}{$\begin{array}{c}P \\
\text { value }\end{array}$} \\
\hline & $\begin{array}{c}\text { No BB } \\
\text { group } \\
(\mathbf{n}=2246)\end{array}$ & $\begin{array}{c}\text { CYP2D6 } \\
\text { group } \\
(n=2246)\end{array}$ & $\begin{array}{c}\text { Non- } \\
\text { CYP2D6 } \\
\text { group } \\
(\mathbf{n}=756)\end{array}$ & \\
\hline \multicolumn{5}{|l|}{ Demographics } \\
\hline Age range (y) & & & & .017 \\
\hline$<55$ & $495(22.0)$ & $464(20.7)$ & $125(16.5)$ & \\
\hline $55-64$ & $648(28.9)$ & $669(29.8)$ & $242(32.0)$ & \\
\hline $65-74$ & $683(30.4)$ & $730(32.5)$ & $258(34.1)$ & \\
\hline $75-84$ & $392(17.4)$ & $344(15.3)$ & $118(15.6)$ & \\
\hline$\geq 85$ & $28(1.2)$ & $39(1.7)$ & $13(1.7)$ & \\
\hline Race & & & & .017 \\
\hline White & $1755(78.1)$ & $1707(76.0)$ & $595(78.7)$ & \\
\hline Black & $368(16.4)$ & 435 (19.4) & $132(17.5)$ & \\
\hline Hispanic & $11(0.5)$ & $15(0.7)$ & $2(0.3)$ & \\
\hline Asian & $19(0.8)$ & $19(0.8)$ & $6(0.8)$ & \\
\hline Native American & $91(4.1)$ & $68(3.0)$ & $21(2.8)$ & \\
\hline Other & $2(0.1)$ & $2(0.1)$ & 0 & \\
\hline Female gender & $643(28.6)$ & $655(29.2)$ & $230(30.4)$ & .641 \\
\hline \multicolumn{5}{|l|}{$\begin{array}{l}\text { EuroSCORE-related } \\
\text { variables }\end{array}$} \\
\hline COPD & $358(15.9)$ & $338(15.0)$ & $74(9.8)$ & .0002 \\
\hline PVD & $324(14.4)$ & $415(18.5)$ & $122(16.1)$ & .001 \\
\hline CVA & $192(8.5)$ & $214(9.5)$ & $93(12.3)$ & .01 \\
\hline $\begin{array}{l}\text { Previous cardiac } \\
\quad \text { surgery }\end{array}$ & $24(1.1)$ & $22(1.0)$ & $6(0.8)$ & .802 \\
\hline $\begin{array}{l}\text { Chronic renal } \\
\text { insufficiency }\end{array}$ & $173(7.7)$ & 267 (11.9) & $50(6.6)$ & $<.0001$ \\
\hline $\begin{array}{l}\text { Critical } \\
\text { preoperative } \\
\text { state }\end{array}$ & $92(4.1)$ & $41(1.9)$ & $13(1.7)$ & $<.0001$ \\
\hline $\begin{array}{l}\text { Unstable angina } \\
\text { pectoris }\end{array}$ & 305 (13.6) & $264(11.8)$ & $121(16.0)$ & .008 \\
\hline $\begin{array}{l}\text { Left ventricular } \\
\text { function }\end{array}$ & & & & $<.0001$ \\
\hline Normal & $1112(49.5)$ & $1066(47.5)$ & $441(58.3)$ & \\
\hline $\begin{array}{l}\text { Moderate } \\
\text { dysfunction }\end{array}$ & $908(40.4)$ & $917(40.8)$ & $273(36.1)$ & \\
\hline $\begin{array}{l}\text { Severe } \\
\text { dysfunction }\end{array}$ & $226(10.1)$ & $263(11.7)$ & $42(5.6)$ & \\
\hline Recent MI & $723(32.2)$ & 485 (21.6) & $146(19.3)$ & $<.0001$ \\
\hline $\begin{array}{l}\text { Pulmonary } \\
\text { hypertension }\end{array}$ & $14(0.6)$ & $16(0.7)$ & $3(0.4)$ & .64 \\
\hline $\begin{array}{l}\text { Emergency } \\
\quad \text { cardiac surgery }\end{array}$ & $194(8.6)$ & $95(4.2)$ & $40(5.3)$ & $<.0001$ \\
\hline $\begin{array}{l}\text { Postinfarct septal } \\
\quad \text { rupture }\end{array}$ & $10(0.4)$ & $1(0.04)$ & $1(0.1)$ & .016 \\
\hline $\begin{array}{l}\text { Average logistic } \\
\text { EuroSCORE }\end{array}$ & $3.5(1.8-7.0)$ & $3.3(1.8-6.8)$ & $3.1(1.7-6.0)$ & .012 \\
\hline Diabetes mellitus & $763(34.0)$ & $841(37.4)$ & $276(36.5)$ & .048 \\
\hline $\begin{array}{l}\text { Preoperative } \\
\text { medications }\end{array}$ & & & & \\
\hline Acetylsalicylic acid & $1012(45.1)$ & $1758(78.3)$ & $570(75.4)$ & $<.0001$ \\
\hline$\alpha$-Receptor blockers & $113(5.0)$ & $132(5.9)$ & $50(6.6)$ & .21 \\
\hline ACE inhibitors & $609(27.1)$ & $1200(53.4)$ & $360(47.6)$ & $<.0001$ \\
\hline
\end{tabular}


TABLE 1. Continued

\begin{tabular}{|c|c|c|c|c|}
\hline \multirow[b]{2}{*}{ Characteristic } & \multicolumn{3}{|c|}{ BBs } & \multirow[b]{2}{*}{$\begin{array}{c}P \\
\text { value }\end{array}$} \\
\hline & $\begin{array}{c}\text { No BB } \\
\text { group } \\
(n=2246)\end{array}$ & $\begin{array}{c}\text { CYP2D6 } \\
\text { group } \\
(n=2246)\end{array}$ & $\begin{array}{c}\text { Non- } \\
\text { CYP2D6 } \\
\text { group } \\
(\mathrm{n}=756)\end{array}$ & \\
\hline $\begin{array}{l}\text { Angiotensin II } \\
\text { receptor } \\
\text { antagonist }\end{array}$ & $188(8.4)$ & $209(9.3)$ & $69(9.1)$ & .527 \\
\hline $\begin{array}{l}\text { Calcium channel } \\
\text { blockers }\end{array}$ & $381(17.0)$ & $412(18.3)$ & $169(22.4)$ & .004 \\
\hline Clopidogrel & $145(6.5)$ & $432(19.2)$ & $123(16.3)$ & $<.0001$ \\
\hline Diuretics & $524(23.3)$ & $752(33.5)$ & $264(34.9)$ & $<.0001$ \\
\hline Nitrates & 334 (14.9) & $957(42.6)$ & $311(41.1)$ & $<.0001$ \\
\hline Statins & $734(32.7)$ & $1461(65.0)$ & $432(57.1)$ & $<.0001$ \\
\hline Warfarin & $74(3.3)$ & $97(4.3)$ & $33(4.4)$ & .16 \\
\hline \multicolumn{5}{|l|}{$\begin{array}{l}\text { Intraoperative } \\
\text { characteristics }\end{array}$} \\
\hline Year of surgery & & & & $<.0001$ \\
\hline 2001 & 435 (19.4) & $365(16.3)$ & $182(24.1)$ & \\
\hline 2002 & $422(18.8)$ & $338(15.0)$ & $143(18.9)$ & \\
\hline 2003 & $303(13.5)$ & $267(11.9)$ & $108(14.3)$ & \\
\hline 2004 & $227(10.1)$ & $208(9.3)$ & 85 (11.2) & \\
\hline 2005 & $212(9.4)$ & $208(9.3)$ & $62(8.2)$ & \\
\hline 2006 & $210(9.3)$ & $198(8.8)$ & $54(7.1)$ & \\
\hline 2007 & $187(8.3)$ & $182(8.1)$ & $52(6.9)$ & \\
\hline 2008 & $154(6.9)$ & $222(9.9)$ & $34(4.5)$ & \\
\hline 2009 & $96(4.3)$ & $258(11.5)$ & $36(4.8)$ & \\
\hline Surgery type & & & & .37 \\
\hline On-pump CABG & $1921(85.5)$ & 1944 (86.6) & $640(84.7)$ & \\
\hline Off-pump CABG & $325(14.5)$ & $302(13.4)$ & $116(15.3)$ & \\
\hline $\begin{array}{l}\text { Duration of CPB } \\
\text { (min) }\end{array}$ & $107.7 \pm 59.9$ & $109.9 \pm 60.6$ & $103.9 \pm 56.4$ & .05 \\
\hline $\begin{array}{l}\text { Aortic crossclamp } \\
\text { time (min) }\end{array}$ & $59.0 \pm 36.7$ & $59.4 \pm 35.4$ & $56.9 \pm 34.2$ & .25 \\
\hline \multicolumn{5}{|l|}{$\begin{array}{l}\text { Intraoperative } \\
\text { medication }\end{array}$} \\
\hline Epinephrine & 1054 (46.9) & $1118(49.8)$ & $291(38.5)$ & $<.0001$ \\
\hline Norepinephrine & $300(13.4)$ & $265(11.8)$ & $81(10.7)$ & .10 \\
\hline Vasopressin & $252(11.2)$ & 289 (12.9) & $58(7.7)$ & .0001 \\
\hline Nitroprusside & $839(37.4)$ & 839 (37.4) & $326(43.1)$ & .01 \\
\hline Nitroglycerin & $1630(72.6)$ & 1637 (72.9) & $558(73.8)$ & .80 \\
\hline Esmolol & $78(3.5)$ & $72(3.2)$ & $24(3.2)$ & .86 \\
\hline Metoprolol & 1497 (66.7) & $1427(63.5)$ & $482(63.8)$ & .071 \\
\hline
\end{tabular}

Data presented as mean \pm standard deviation, median (interquartile range), or $\mathrm{n}(\%)$. $B B, \beta$-Blocker; EuroSCORE, European System for Cardiac Operative Risk Evaluation score; $C O P D$, chronic obstructive pulmonary disease; $P V D$, peripheral vascular disease; CVA, cerebrovascular accident; $M I$, myocardial infarction; $A C E$, angiotensin-converting enzyme; $C A B G$, coronary artery bypass grafting; $C P B$, cardiopulmonary bypass. *The definitions of these risk factors were determined from the definitions (Table E1) used by the EuroSCORE scoring system. ${ }^{12}$

In multivariable analysis, a higher logistic EuroSCORE, intraoperative administration of epinephrine and norepinephrine, and an increased duration of cardiopulmonary bypass remained significant predictors of operative mortality (Table 2). Preoperative aspirin and statin use and intraoperative administration of metoprolol were associated with decreased operative mortality. After correcting for differences in the preoperative and intraoperative characteristics, only preoperative non-CYP2D6_BB use was significantly associated with a lower incidence of operative mortality compared with patients who did not take BBs (OR, 0.34; 95\% CI, 0.14-0.81; $P=.015$; Table 2).

After IPW-adjusted multivariable analysis, the association between preoperative non-CYP2D6_BB use and a lower incidence of operative mortality compared with no BB use remained significant (OR, 0.33; 95\% CI, 0.14-0.86; $P=.02$; Table 2). The final IPW-adjusted multivariable logistic regression model for all-cause operative mortality showed good discriminative ability and good fit (c-index, 0.775; overall goodness-of-fit Hosmer-Lemeshow test, chi-square $=6.91 ; P=.55)$. The degree of overoptimism was minimal at 0.004 , which resulted in an adjusted c-index of 0.779 .

In a secondary analysis, we also tested a hypothesis of whether the type of $\mathrm{BB}$ use was associated with mortality by directly comparing CYP2D6_BBs and nonCYP2D6_BBs and found a trend toward lower all-cause operative mortality for non-CYP2D6_BB treatment on IPW-adjusted multivariable analysis (OR, 0.44; 95\% CI, 0.16-1.07; $P=.06$ ).

\section{DISCUSSION}

To our knowledge, this is the first study to compare the risk of operative mortality among CYP2D6_BB, nonCYP2D6_BB, and no BB use groups in a large population undergoing $\mathrm{CABG}$ surgery. The operative mortality was lower for the patients who had received nonCYP2D6_BBs preoperatively than for the patients who had received no preoperative BBs. We found, however, no difference in operative mortality between patients taking CYP2D6_BBs and those without preoperative BB therapy.

Our finding that metabolism by way of the CYP2D6 pathway might be associated with the efficacy of BBs has been supported by previous pharmacogenomic studies, ${ }^{13-15}$ which have demonstrated an association between CYP2D6 genotype and the pharmacokinetics of BBs, particularly metoprolol. The effect of the CYP2D6 genotype appears to be large. According to clinical studies, CYP2D6 PMs had 3- to 10-fold greater plasma concentrations of metoprolol than did subjects who were extensive metabolizers with normal CYP2D6 activity. ${ }^{13,16}$ Furthermore, the elimination half-life of metoprolol was found to be 7.5 hours in PMs versus 2.8 hours in extensive metabolizers. ${ }^{13}$ In a recent prospective trial, the plasma concentrations of metoprolol were 4.9-fold higher in the PMs than in the non-PMs, although the dosing was similar. ${ }^{5}$ This difference in the plasma concentrations of metoprolol was associated with significantly and persistently increased drug effects in the PMs, resulting in greater reductions in heart rate, diastolic blood pressure, and mean arterial pressure than in the non-PMs. The more pronounced heart rate-lowering effect in PMs was also supported by a study by Wuttke and 
TABLE 2. Univariable and multivariable predictors of operative mortality

\begin{tabular}{|c|c|c|c|c|c|c|}
\hline \multirow[b]{2}{*}{ Variable } & \multicolumn{2}{|c|}{ Univariable analysis } & \multicolumn{2}{|c|}{ Multivariable analysis } & \multicolumn{2}{|c|}{$\begin{array}{c}\text { Multivariable analysis, } \\
\text { propensity adjusted }\end{array}$} \\
\hline & OR $(95 \%$ CI $)$ & $P$ value & OR $(95 \%$ CI $)$ & $P$ value & OR $(95 \%$ CI $)$ & $P$ value \\
\hline \multicolumn{7}{|l|}{ Demographics } \\
\hline \multicolumn{7}{|l|}{ Race } \\
\hline White & 1.0 & & & & & \\
\hline Black & $0.78(0.48-1.27)$ & .32 & & & & \\
\hline Hispanic & $<0.001(<0.001->999.99)$ & .99 & & & & \\
\hline Asian & $0.83(0.11-6.12)$ & .86 & & & & \\
\hline Native American & $1.24(0.54-2.85)$ & .62 & & & & \\
\hline Other & $<0.001(<0.001->999.99)$ & .99 & & & & \\
\hline \multicolumn{7}{|l|}{ Patient characteristics } \\
\hline Diabetes mellitus & $0.87(0.61-1.25)$ & .46 & & & & \\
\hline Logistic EuroSCORE per 1\% increase & $1.07(1.06-1.08)$ & $<.0001$ & $1.06(1.05-1.07)$ & $<.0001$ & $1.05(1.04-1.07)$ & $<.0001$ \\
\hline \multicolumn{7}{|l|}{ Preoperative medication } \\
\hline Acetylsalicylic acid & $0.41(0.29-0.58)$ & $<.0001$ & $0.60(0.41-0.87)$ & .008 & $0.57(0.35-0.92)$ & .021 \\
\hline$\alpha$-Receptor blockers & $0.37(0.12-1.17)$ & .09 & & & & \\
\hline ACE inhibitors & $0.69(0.48-0.98)$ & .04 & & & & \\
\hline Angiotensin II receptor antagonists & $0.46(0.20-1.06)$ & .07 & & & & \\
\hline \multicolumn{7}{|l|}{ BB use } \\
\hline No BB group & 1.0 & & 1.0 & & 1.0 & \\
\hline CYP2D6 group & $0.56(0.39-0.82)$ & .002 & $0.86(0.59-1.23)$ & .40 & $0.85(0.54-1.34)$ & .48 \\
\hline Non-CYP2D6 group & $0.21(0.09-0.48)$ & $<.0001$ & $0.34(0.14-0.81)$ & .015 & $0.33(0.13-0.83)$ & .02 \\
\hline Calcium channel blockers & $0.85(0.54-1.35)$ & .49 & & & & \\
\hline Clopidogrel & $0.98(0.59-1.62)$ & .94 & & & & \\
\hline Diuretics & $0.89(0.61-1.30)$ & .54 & & & & \\
\hline Nitrates & $0.87(0.60-1.27)$ & .47 & & & & \\
\hline Statins & $0.46(0.32-0.67)$ & $<.0001$ & $0.61(0.42-0.90)$ & .012 & $0.55(0.33-0.90)$ & .02 \\
\hline Warfarin & $1.34(0.62-2.91)$ & .46 & & & & \\
\hline \multicolumn{7}{|l|}{ Intraoperative characteristics } \\
\hline Year of surgery per year & $0.99(0.93-1.06)$ & .72 & & & & \\
\hline $\mathrm{CPB}$ time per $10 \mathrm{~min}$ & $1.06(1.04-1.09)$ & $<.0001$ & $1.05(1.02-1.08)$ & .0003 & $1.05(1.01-1.08)$ & .01 \\
\hline Epinephrine & $2.53(1.76-3.65)$ & $<.0001$ & $1.57(1.05-2.34)$ & .028 & $1.96(1.21-3.19)$ & .007 \\
\hline Esmolol & $0.65(0.20-2.05)$ & .46 & & & & \\
\hline Metoprolol & $0.54(0.38-0.76)$ & $<.0001$ & $0.62(0.43-0.89)$ & .009 & $0.60(0.38-0.95)$ & .03 \\
\hline Norepinephrine & $1.70(1.10-2.62)$ & .02 & $1.62(1.01-2.62)$ & .048 & $1.62(0.88-2.98)$ & .12 \\
\hline Vasopressin & $2.14(1.41-3.25)$ & $<.0001$ & & & & \\
\hline Nitroprusside & $0.96(0.68-1.36)$ & .82 & & & & \\
\hline Nitroglycerin & $0.90(0.62-1.31)$ & .58 & & & & \\
\hline
\end{tabular}

$\overline{O R}$, Odds ratio; $C I$, confidence interval; EuroSCORE, European System for Cardiac Operative Risk Evaluation score; $A C E$, angiotensin-converting enzyme; $B B, \beta$-blocker; $C P B$, cardiopulmonary bypass.

colleagues. ${ }^{9}$ They found an overrepresentation of patients with the PM genotype among patients with metoprololassociated adverse effects such as bradycardia. In a study by Kirchheiner and colleagues, ${ }^{17}$ metoprolol use in PMs was associated with a more pronounced lowering of exercise-induced tachycardia. Because the plasma concentration of metoprolol is determined largely by CYP2D6 activity, the observed reduction in exerciseinduced tachycardia was an indication of the effect of CYP2D6 PM status. ${ }^{18}$

In a recent meta-analysis, Badgett and colleagues ${ }^{10}$ observed that the benefit of BBs in patients undergoing noncardiac surgery was reduced for BBs with the CYP2D6 metabolism. Increased mortality from perioperative BBs was confined to trials that had used BBs with the CYP2D6 metabolism. These findings also indicated that patients using BBs with the CYP2D6 metabolism were more susceptible to bradycardia, likely caused by lower functioning genetic polymorphisms. Of importance, patients who are ultrarapid metabolizers might be at greater risk of operative mortality, because increased activity of the CYP2D6 isoenzyme has been associated with insufficient CYP2D6_BB exposure ${ }^{19}$ compared with extensive metabolizers (normal phenotype) who will have sufficient CYP2D6_BB exposure. However, patients who are PMs might be at high risk of operative mortality because of excessive CYP2D6_BB exposure. Our observation of increased intraoperative requirements for both epinephrine 
and vasopressin in the CYP2D6_BB group compared with the non-CYP2D6_BB group (Table 1) is consistent with this mechanism. Given that the prevalence of ultrarapid metabolizers is low ( $2 \%-3 \%$ in whites), the lack of efficacy of CYP2D6_BBs compared with no BB use observed in our study was likely a result of the combined effect of sufficient exposure and too much exposure to CYP2D6_BBs.

BBs are known to differ in their pharmacokinetic and pharmacodynamic properties. The assumption that the potential benefits in patients with different cardiovascular conditions relate to a class effect might be incorrect. Differences in half life, volume of distribution, protein binding, and route of elimination could result in differences in the duration, side effects, and efficacy of BBs. Several large studies have investigated the relationship between BB therapy and perioperative ischemic outcomes. In a group of 37,151 patients who had undergone orthopedic and abdominal surgery, Redelmeier and colleagues ${ }^{20}$ found that the risk of myocardial infarction and mortality was lower in patients who had received atenolol than in those who had received metoprolol. Wallace and colleagues ${ }^{21}$ studied a group of 6563 patients who had undergone noncardiac surgery and found that perioperative $\beta$-blockade with atenolol was associated with reduced short- and long-term mortality compared with metoprolol. In a recent study, London and colleagues ${ }^{11}$ also studied a group of 75,610 propensity-matched patients who had undergone noncardiac surgery and found that perioperative exposure to atenolol was associated with a significantly lower incidence of mortality and stroke than was metoprolol. Such anti-ischemic effects and differences in specific BB type appear to be linked to adequate heart rate control. According to results of a meta-analysis of randomized trials of $\mathrm{BB}$ in noncardiac surgery by Beattie and colleagues, ${ }^{22}$ effective control of the heart rate was associated with the greatest reduction in the incidence of postoperative myocardial infarction. Importantly, BBs other than metoprolol resulted in more effective control of the heart rate and less variability in the heart rate response. The reasons for inadequate heart rate response to BBs such as metoprolol could be multifactorial; however, pharamacokinetic properties, including the metabolic pathway, might significantly influence the efficacy of BBs. Nevertheless, several other genetic and nongenetic factors are also likely to contribute to the response and efficacy of BBs. Such genetic factors include polymorphisms in the adrenergic signaling pathway, introducing pharmacodynamic variability, ${ }^{10}$ and nongenetic factors, such as drug-drug interactions, release or dissolution, absorption, and intestinal first-pass extraction. ${ }^{23}$ Furthermore, the $\beta_{1}$-adrenergic receptor selectivity of atenolol (the typical non-CYP2D6_BB in our cohort) is twice superior to that of metoprolol (the typical CYP2D6_BB). ${ }^{10}$ Given the retrospective nature of our study, we were unable to explore all the genetic and nongenetic factors that might influence the efficacy of BBs.

\section{Study Limitations}

As is common with retrospective study designs, our study had several limitations. Information on some important predictors of operative mortality was not prospectively collected. We used electronic medical records and physician documentation to collect additional data on the clinical risk factors and medication use, including type of preoperative BBs. Thus, the effect of some risk factors and medication use might have been biased. However, their predictive values were similar to those reported by others and in current guidelines. ${ }^{1}$

Although the propensity score analysis adjusted for known confounders, other unmeasured confounders could not be accounted for and the possibility of residual confounding by indication could not be completely ruled out. In addition, we defined the type of preoperative BB as treatment received at any dose within 24 hours before surgery. Therefore, BB therapy might not have been optimized for all patients and the observed differences in outcomes might have been altered if a standardized treatment regimen had been used. Finally, our analysis was restricted to the preoperative administration of BBs and, given the retrospective design of our study, we could not account for the continuation and type of BB therapy after surgery. The potential mechanisms by which preoperatively administered $\mathrm{BBs}$ might have the influenced surgical outcome after CABG in our study are unknown; however, factors such as a more pronounced sympathetic rebound with the shorter half-life of preoperatively administered metoprolol, ${ }^{20}$ the extent of BB metabolism by CYP2D6 resulting in inconsistent sympatholysis, or variations in $\mathrm{BB}$ selectivity for the $\beta_{1}$-adrenergic receptor associated with reduced cerebral and renal protection could all have contributed to an increased risk of postoperative mortality. ${ }^{10}$

Within the P-450 superfamily of drug-metabolizing enzymes, CYP2D6 accounts for the metabolism of $25 \%$ of marketed drugs including BBs, antidepressants, opioids, anti-arrhythmics, and antihistamines. Many of these drugs are substrates, inhibitors, or inducers of the CYP2D6 enzyme, and concomitant administration of a substrate with an inhibitor or an inducer can lead to unwanted drug-drug interactions, with implications for patient safety in the clinical setting. ${ }^{24}$ Given the retrospective nature of our study, we could not account for the list of medications that would potentially be associated with drug-drug interactions with CYP2D6_BBs and operative mortality. However, the administration of a potent CYP2D6 inhibitor would not be expected to cause a marked CYP2D6 drug-drug interaction for those exhibiting the PM phenotype. In contrast, CYP2D6-mediated drug-drug 
interactions might be observed in those who exhibit the ultrarapid, extensive, or intermediate metabolizer phenotype. ${ }^{19,25}$ Finally, we used all-cause operative mortality, rather than cardiac mortality, as our endpoint, which could have resulted in a spurious association between non-CYP2D6_BB use and outcome.

\section{CONCLUSIONS}

In patients undergoing $\mathrm{CABG}$ surgery, preoperative non-CYP2D6_BB use was associated with lower operative mortality after CABG surgery. However, preoperative CYP2D6_BB use was not associated with lower shortterm mortality.

Our findings and those from former pharmacogenomic studies represent a step forward toward personalizing the clinical strategies to minimize perioperative cardiac complications and lower operative mortality according to genotype. The robust association between the CYP2D6 genotype and pharmacokinetics of CYP2D6-dependent BBs has provided strong evidence that the CYP2D6 genotype might influence the efficacy of BBs such as metoprolol. ${ }^{5,9,10}$ An obvious clinical implication of the personalized perioperative $\mathrm{BB}$ use could be genetic testing for CYP2D6 variant alleles, especially in patients with a history of side effects from BB use or in patients starting to use CYP2D6-dependent BBs. The results of such genetic testing could lead physicians in the perioperative setting to consider lowering the dose of CYP2D6-dependent $\mathrm{BBs}$ in $\mathrm{PMs}^{5,9,10}$ or increasing the dose in ultrarapid metabolizers $^{19}$ or to consider alternative therapy using CYP2D6-independent BBs such as atenolol or bisoprolol. ${ }^{10}$ Information on the CYP2D6 genotype could also help individualize the titration of perioperative analgesic, antiarrhythmic, and antiemetic drugs that depend on the CYP2D6 metabolism, thereby preventing adverse effects. ${ }^{25}$

The authors thank Betsy Hale (data analyst) for help with data retrieval and database building. They also thank Matthew Yurkoski Gray (research associate), Aaron Reynolds, MD (Duke Cardiothoracic Anesthesiology Fellow), and Robert Sickeler, BA (medical student) for help with data retrieval. Finally, the authors thank Kathy Gage (research development associate) for her editorial contributions to the final report. All are associated with the Department of Anesthesiology, Duke University Medical Center, Durham, NC.

\section{References}

1. Hillis LD, Smith PK, Anderson JL, Bittl JA, Bridges CR, Bryne JG, et al. 2011 ACCF/AHA guideline for coronary artery bypass graft surgery: a report of the American College of Cardiology Foundation/American Heart Association Task Force on Practice Guidelines, developed in collaboration with the American Association for Thoracic Surgery, Society of Cardiovascular Anesthesiologists, and Society of Thoracic Surgeons. J Am Coll Cardiol. 2011;58:e123-210.

2. Domanski MJ, Mahaffey K, Hasselblad V, Brener SJ, Smith PK, Hillis G, et al. Association of myocardial enzyme elevation and survival following coronary artery bypass graft surgery. JAMA. 2011;305:585-91.
3. Ferguson TB Jr, Coombs LP, Peterson ED. Preoperative beta-blocker use and mortality and morbidity following CABG surgery in North America. JAMA. 2002;287:2221-7.

4. POISE Study Group, Devereaux PJ, Yang H, Yusuf S, Guyatt G, Leslie K, Villar JC, et al. Effects of extended-release metoprolol succinate in patients undergoing non-cardiac surgery (POISE trial): a randomised controlled trial. Lancet. 2008;371:1839-47.

5. Rau T, Wuttke H, Michels LM, Werner U, Bergmann K, Kreft M, et al. Impact of the CYP2D6 genotype on the clinical effects of metoprolol: a prospective longitudinal study. Clin Pharmacol Ther. 2009;85:269-72.

6. Bangalore S, Steg G, Deedwania P, Crowley K, Eagle KA, Goto S, et al. $\beta$-Blocker use and clinical outcomes in stable outpatients with and without coronary artery disease. JAMA. 2012;308:1340-9.

7. Zhou SF. Polymorphism of human cytochrome P450 2D6 and its clinical significance: part I. Clin Pharmacokinet. 2009;48:689-723.

8. Bijl MJ, Visser LE, van Schaik RH, Kors JA, Witteman JC, Hofman A, et al. Genetic variation in the CYP2D6 gene is associated with a lower heart rate and blood pressure in beta-blocker users. Clin Pharmacol Ther. 2009;85: 45-50.

9. Wuttke H, Rau T, Heide R, Bergmann K, Böhm M, Weill J, et al. Increased frequency of cytochrome P450 2D6 poor metabolizers among patients with metoprolol-associated adverse effects. Clin Pharmacol Ther. 2002;72:429-37.

10. Badgett RG, Lawrence VA, Cohn SL. Variations in pharmacology of betablockers may contribute to heterogeneous results in trials of perioperative beta-blockade. Anesthesiology. 2010;113:585-92.

11. London MJ, Hur K, Schwartz GG, Henderson WG. Association of perioperative $\beta$-blockade with mortality and cardiovascular morbidity following major noncardiac surgery. JAMA. 2013;309:1704-13.

12. Nashef SA, Roques F, Michel P, Gauducheau E, Lemeshow S, Salamon R European system for cardiac operative risk evaluation (EuroSCORE) Eur J Cardiothorac Surg. 1999;16:9-13.

13. Lennard MS, Silas JH, Freestone S, Ramsay LE, Tucker GT, Woods HF. Oxidation phenotype - a major determinant of metoprolol metabolism and response. N Engl J Med. 1982;307:1558-60.

14. McGourty JC, Silas JH, Lennard MS, Tucker GT, Woods HF. Metoprolol metabolism and debrisoquine oxidation polymorphism-population and family studies. Br J Clin Pharmacol. 1985;20:555-66.

15. Rau T, Heide R, Bergmann K, Wuttke H, Werner U, Feifel N. Effect of the CYP2D6 genotype on metoprolol metabolism persists during long-term treatment. Pharmacogenetics. 2002;12:465-72.

16. Deroubaix X, Lins RL, Lens S, Demblon C, Jeanbaptiste B, Poelaert D, et al. Comparative bioavailability of a metoprolol controlled release formulation and a bisoprolol normal release tablet after single oral dose administration in healthy volunteers. Int J Clin Pharmacol Ther. 1996;34:61-70.

17. Kirchheiner J, Heesch C, Bauer S, Meisel C, Seringer A, Goldammer M, et al. Impact of the ultrarapid metabolizer genotype of cytochrome P450 2D6 on metoprolol pharmacokinetics and pharmacodynamics. Clin Pharmacol Ther. 2004; 76:302-12.

18. Beitelshees AL, Zineh I, Yarandi HN, Pauly DF, Johnson JA. Influence of phenotype and pharmacokinetics on beta-blocker drug target pharmacogenetics. Pharmacogenom J. 2006;6:174-8.

19. Goryachkina K, Burbello A, Boldueva S, Babak S, Bergman U, Bertilsson L. CYP2D6 is a major determinant of metoprolol disposition and effects in hospitalized Russian patients treated for acute myocardial infarction. Eur J Clin Pharmacol. 2008;64:1163-73.

20. Redelmeier D, Scales D, Kopp A. Beta blockers for elective surgery in elderly patients: population based, retrospective cohort study. BMJ. 2005;331:932.

21. Wallace AW, Au S, Cason BA. Perioperative beta-blockade: atenolol is associated with reduced mortality when compared to metoprolol. Anesthesiology. 2011;114:824-36.

22. Beattie WS, Wijeysundera DN, Karkouti K, McCluskey S, Tait G. Does tight heart rate control improve beta-blocker efficacy? An updated analysis of the noncardiac surgical randomized trials. Anesth Analg. 2008;106:1039-48.

23. Lukacova V, Woltosz WS, Bolger MB. Prediction of modified release pharmacokinetics and pharmacodynamics from in vitro, immediate release, and intravenous data. AAPS J. 2009;11:323-34.

24. VandenBrink BM, Foti RS, Rock DA, Wienkers LC, Wahlstrom JL. Prediction of CYP2D6 drug interactions from in vitro data: evidence for substrate-dependent inhibition. Drug Metab Dispos. 2012;40:47-53.

25. Zhou SF. Polymorphism of human cytochrome P450 2D6 and its clinical significance: part II. Clin Pharmacokinet. 2009;48:761-804. 


\section{APPENDIX}

The members of the CARE Group are listed below.

Anesthesiology: Solomon Aronson, MD, Brandi A. Bottiger, MD, Brian J. Colin, MD, J. Mauricio del Rio, MD, Manuel L. Fontes, MD, Katherine P. Grichnik, MD, Nicole R. Guinn, MD, Joern A. Karhausen, MD, Miklos D. Kertai, MD, F. Willem Lombard, MD, Michael W. Manning, MD, Joseph P. Mathew, MD, Grace C. McCarthy, MD, Mark F. Newman, MD, Alina Nicoara, MD, Mihai V. Podgoreanu, MD, Mark Stafford-Smith, MD, Madhav Swaminathan, MD, Ian J. Welsby, MD, George B. Whitener, MD, Stephanie K. Whitener, MD

Anesthesiology Clinical Research Services: Narai Balajonda, MD, Tiffany Bisanar, RN, Bonita L. Funk, RN,
Roger L. Hall, AAS, Kathleen Lane, RN, BSN, Yi-Ju Li, $\mathrm{PhD}$, Greg Pecora, BA, Barbara Phillips-Bute, PhD, Prometheus T. Solon, MD, Yanne Toulgoat-Dubois, BA, Peter Waweru, CCRP, William D. White, MPH

Perfusion Services: Stanlin Alexander, BS, CCP, Kevin Collins, BS, CCP, Ian Shearer, BS, CCP, Greg Smigla, $\mathrm{BS}, \mathrm{CCP}$

Surgery: Mark F. Berry, MD, Thomas A. D'Amico, MD, R. Duane Davis, MD, Jeffrey G. Gaca, MD, Donald D. Glower, MD, R. David Harpole, MD, Matthew G. Hartwig, MD, G. Chad Hughes, MD, Robert D.B. Jaquiss, MD, Shu S. Lin, MD, Andrew J. Lodge, MD, Carmelo A. Milano, MD, Charles E. Murphy, MD, Mark W. Onaitis, MD, Jacob N. Schroeder, MD, Peter K. Smith, MD, Betty C. Tong, MD 


\section{SUPPLEMENTAL METHODS \\ Statistical Analysis}

Inverse probability weighting and treatment model. We used the inverse probability weighting (IPW) estimators to control for treatment selection. ${ }^{\mathrm{El}}$ The IPW creates a pseudopopulation in which each predictor of treatment, including demographic characteristics, medical history characteristics, and baseline medications, becomes balanced among the 3 groups. Three steps in this modeling include estimation of a treatment model, calculation of individual weights, and analysis of the outcome of interest for weighted observations.

Because the response variable (treatment group) is nominal, we used the multinomial (or generalized) logistic model to represent the treatment in terms of the predictors of treatment:

$$
\log \left(\frac{\operatorname{Pr}\left(T=i \mid x_{1}, \ldots, x_{K}\right)}{\operatorname{Pr}\left(T=0 \mid x_{1}, \ldots, x_{K}\right)}\right)=\alpha_{i}+\sum_{k=1}^{K} \beta_{i k} x_{k}, \quad i=0,1,2
$$

where $\alpha_{i}$ are the 3 intercept parameters and $\beta_{i k}$ are $3 K$ slope parameters. The following variables were used as predictors: age, race, female gender, chronic obstructive pulmonary disease, peripheral vascular disease, cerebrovascular accident, previous cardiac surgery, chronic renal insufficiency, critical preoperative state, unstable angina pectoris, left ventricular function, recent myocardial infarction, pulmonary hypertension, emergency cardiac surgery, postinfarct septal rupture, diabetes mellitus, preoperative acetylsalicylic acid use, preoperative $\alpha$-receptor blocker use, preoperative angiotensin-converting enzyme inhibitor use, preoperative angiotensin II receptor antagonist use, preoperative calcium channel blocker use, preoperative clopidogrel, preoperative diuretic use, preoperative nitrate use, preoperative statin use, preoperative warfarin use, and year of surgery.

The model parameters were estimated by the method of maximum likelihood using SAS Proc LOGISTIC. The estimated parameters allowed for estimating the linear predictors $\eta_{i}=\alpha_{i}+\sum_{k=1}^{K} \beta_{i k} x_{k}$ and the individual probabilities $\pi_{i}$ for obtaining the response value $i$ as follows:

$$
\pi_{0}=\frac{1}{1+\sum_{i=1}^{2} \exp \left(\eta_{\mathrm{i}}\right)}
$$

for referent treatment $(i=0)$ and

$$
\pi_{i}=\pi_{0} \exp \left(\eta_{\mathrm{i}}\right)
$$

for $i=1$ or 2 . As one can see, $\pi_{0}+\pi_{1}+\pi_{2}=1$. The estimated probabilities were used to estimate the individual weights $w$ as reciprocal of the probability to have the actually observed treatment (ie, $w=1 / \pi_{\bar{i}}$ ), where $\bar{i}(\bar{i}$ could be 0,1 , or 2$)$ is the treatment observed for the given patient.

\section{Discriminatory Power}

To further evaluate the discriminatory power of the final multivariable model, the bootstrap method using 1000 bootstrap samples of the size of the original cohort was used to assess the degree of overoptimism. Overoptimization occurs when application of the statistical modeling techniques results in models that inaccurately predict the outcomes on subsequent data sets. A bootstrapping procedure is 1 method that can be used to try to correct for this overoptimism. ${ }^{\mathrm{E} 2}$ The distribution of the c-index statistics was evaluated and compared for the calculations with and without the weights adjusting the results of treatment selection.

\section{E-References}

E1. Austin PC. The performance of different propensity-score methods for estimating differences in proportions (risk differences or absolute risk reductions) in observational studies. Stat Med. 2010;29:2137-48.

E2. Babyak MA. What you see may not be what you get: a brief, nontechnical introduction to overfitting in regression-type models. Psychosom Med. 2004; 66:411-21. 
TABLE E1. Definition of variables in the EuroSCORE risk model

\begin{tabular}{|c|c|}
\hline Risk factor & STS definition match \\
\hline 1. Age & Per 5 y or part thereof $>60 y$ \\
\hline 2. Gender & Female \\
\hline 3. Chronic pulmonary disease & $\begin{array}{l}\text { Patient requires pharmacologic therapy for treatment of chronic pulmonary compromise or patient had } \\
\mathrm{FEV}_{1}<75 \% \text { of predicted value }\end{array}$ \\
\hline 4. Extracardiac arteriopathy & $\begin{array}{l}\text { Patient has peripheral vascular disease as indicated by claudication with either exertion or rest; amputation for } \\
\text { arterial insufficiency; aortoiliac occlusive disease reconstruction; peripheral vascular bypass surgery; } \\
\text { angioplasty or stent; documented abdominal aortic aneurysm, abdominal aortic aneurysm repair, or stent; } \\
\text { positive noninvasive testing documented-or-patient has cerebrovascular disease, documented by any } 1 \text { of the } \\
\text { following: unresponsive coma for }>24 \mathrm{~h} \text {; CVA (symptoms for }>72 \mathrm{~h} \text { after onset); RIND (recovery within } 72 \mathrm{~h} \text { ); } \\
\text { TIA (recovery within } 24 \mathrm{~h} \text { ); or noninvasive carotid test results with } 75 \% \text { occlusion }\end{array}$ \\
\hline 5. Neurologic dysfunction disease & A central neurologic deficit persisting $>24 \mathrm{~h}$ \\
\hline 6. Previous cardiac surgery & Previous cardiac surgical operations with or without $\mathrm{CPB}$ \\
\hline 7. Serum creatinine & $>200 \mathrm{mmol} / \mathrm{L}$ preoperatively \\
\hline 9. Critical preoperative state & $\begin{array}{l}\text { Any } \geq 1 \text { of the following: sustained ventricular tachycardia or ventricular fibrillation requiring cardioversion and/ } \\
\text { or intravenous amiodarone, preoperative inotropic support, preoperative intra-aortic balloon pump, or patient } \\
\text { required cardiopulmonary resuscitation within } 1 \mathrm{~h} \text { before the start of the operative procedure }\end{array}$ \\
\hline 10. Unstable angina & Preoperative use of intravenous nitrates \\
\hline 11. Left ventricular dysfunction & Normal, LVEF $>50 \%$; moderate, LVEF 30\%-50\%; severe, LVEF $<30 \%$ \\
\hline 12. Recent MI & $<21 \mathrm{~d}$ \\
\hline 13. Pulmonary hypertension & Systolic pulmonary artery pressure $>30 \mathrm{~mm} \mathrm{Hg}$ \\
\hline 14. Emergency & $\begin{array}{l}\text { Procedure status is emergent or salvage. Emergent: the patient's clinical status includes any of the following: (1) } \\
\text { ischemic dysfunction (any of the following): (a) ongoing ischemia, including ret angina despite maximal } \\
\text { medical therapy (medical and/or IABP); (b) acute evoking myocardial infarction within } 24 \mathrm{~h} \text { before surgery; } \\
\text { and/or (c) pulmonary edema requiring intubation; (2) mechanical dysfunction (either of the following): (a) } \\
\text { shock with circulatory support; or (b) shock without circulatory support. Salvage: the patient is undergoing CPR } \\
\text { en route to the OR or before anesthesia induction }\end{array}$ \\
\hline 15. Other than isolated CABG & Any valve procedure in addition to or separate from $\mathrm{CABG}$ \\
\hline 16. Surgery on thoracic aorta & Aortic aneurysm/dissection repair \\
\hline 17. Postinfarct septal rupture & Ventricular septal defect \\
\hline
\end{tabular}

EuroSCORE, European System for Cardiac Operative Risk Evaluation score; STS, Society of Thoracic Surgery; $F E V_{l}$, forced expiratory volume in 1 second; RIND, reversible ischemic neurologic deficit; $T I A$, transient ischemic attack; $L V E F$, left ventricular ejection fraction; $M I$, myocardial infarction; $I A B P$, intra-aortic balloon pump; $C P R$, cardiopulmonary resuscitation; $O R$, operating room; $C A B G$, coronary artery bypass grafting. Data from Nashef SA, Roques F, Michel P, Gauducheau E, Lemeshow S, Salamon R. European system for cardiac operative risk evaluation (EuroSCORE). Eur J Cardiothorac Surg. 1999;16:9-13. 
TABLE E2. Baseline characteristics after propensity score adjustment $(\mathbf{n}=\mathbf{5 2 4 8})$

\begin{tabular}{|c|c|c|c|c|}
\hline \multirow[b]{2}{*}{ Characteristic } & \multicolumn{3}{|c|}{ BBs } & \multirow[b]{2}{*}{$\begin{array}{c}P \\
\text { value } \\
\end{array}$} \\
\hline & $\begin{array}{c}\text { No BB } \\
\text { group } \\
(\mathrm{n}=2246) \\
\end{array}$ & $\begin{array}{c}\text { CYP2D6 } \\
\text { group } \\
(n=2246) \\
\end{array}$ & $\begin{array}{c}\text { Non-CYP2D6 } \\
\text { group } \\
(\mathbf{n}=756) \\
\end{array}$ & \\
\hline \multicolumn{5}{|l|}{ Demographics } \\
\hline Age range (y) & & & & .37 \\
\hline$<55$ & 20.49 & 19.92 & 16.92 & \\
\hline $55-64$ & 29.23 & 29.34 & 32.21 & \\
\hline $65-74$ & 31.17 & 32.42 & 33.85 & \\
\hline $75-84$ & 17.67 & 16.6 & 15.29 & \\
\hline$\geq 85$ & 1.44 & 1.74 & 1.74 & \\
\hline Race & & & & .37 \\
\hline White & 77.97 & 76.02 & 77.31 & \\
\hline Black & 17.65 & 19.61 & 18.3 & \\
\hline Hispanic & 0.43 & 0.63 & 0.35 & \\
\hline Asian & 0.8 & 1.01 & 0.88 & \\
\hline Native American & 3.05 & 2.68 & 3.16 & \\
\hline Other & 0.09 & 0.05 & 0 & \\
\hline Female gender & 30.21 & 29.51 & 30.08 & .94 \\
\hline \multicolumn{5}{|l|}{ Medical history } \\
\hline \multicolumn{5}{|l|}{$\begin{array}{c}\text { EuroSCORE- } \\
\text { related } \\
\text { variables* }\end{array}$} \\
\hline COPD & 15.75 & 15.43 & 14.41 & .74 \\
\hline PVD & 16.85 & 16.92 & 17.53 & .91 \\
\hline CVA & 10.0 & 10.0 & 10.44 & .93 \\
\hline $\begin{array}{l}\text { Previous cardiac } \\
\text { surgery }\end{array}$ & 1.03 & 1.07 & 1.17 & .96 \\
\hline $\begin{array}{l}\text { Chronic renal } \\
\text { insufficiency }\end{array}$ & 36.56 & 36.77 & 35.94 & .93 \\
\hline $\begin{array}{l}\text { Critical } \\
\text { preoperative } \\
\text { state }\end{array}$ & 2.63 & 2.68 & 2.63 & .99 \\
\hline $\begin{array}{l}\text { Unstable angina } \\
\text { pectoris }\end{array}$ & 12.26 & 12.84 & 13.29 & .77 \\
\hline $\begin{array}{l}\text { Left ventricular } \\
\text { function }\end{array}$ & & & & .27 \\
\hline Normal & 49.46 & 50.98 & 50.47 & \\
\hline $\begin{array}{l}\text { Moderate } \\
\text { dysfunction }\end{array}$ & 41.85 & 39.03 & 42.13 & \\
\hline $\begin{array}{l}\text { Severe } \\
\quad \text { dysfunction }\end{array}$ & 8.69 & 9.99 & 7.39 & \\
\hline Recent MI & 23.35 & 23.29 & 25.24 & .54 \\
\hline $\begin{array}{l}\text { Pulmonary } \\
\text { hypertension }\end{array}$ & 0.61 & 0.94 & 0.41 & .40 \\
\hline $\begin{array}{l}\text { Emergency } \\
\text { cardiac } \\
\text { surgery }\end{array}$ & 5.75 & 5.73 & 6.2 & .89 \\
\hline $\begin{array}{l}\text { Postinfarct septal } \\
\text { rupture }\end{array}$ & 0.2 & 0.04 & 0.08 & .26 \\
\hline Diabetes mellitus & 10.65 & 9.7 & 9.55 & .74 \\
\hline \multicolumn{5}{|l|}{$\begin{array}{l}\text { Preoperative } \\
\text { medications }\end{array}$} \\
\hline Acetylsalicylic acid & 66.26 & 66.58 & 66.79 & .97 \\
\hline
\end{tabular}

TABLE E2. Continued

\begin{tabular}{|c|c|c|c|c|}
\hline \multirow[b]{2}{*}{ Characteristic } & \multicolumn{3}{|c|}{ BBs } & \multirow[b]{2}{*}{$\begin{array}{c}P \\
\text { value }\end{array}$} \\
\hline & $\begin{array}{c}\text { No BB } \\
\text { group } \\
(\mathbf{n}=\mathbf{2 2 4 6}) \\
\end{array}$ & $\begin{array}{c}\text { CYP2D6 } \\
\text { group } \\
(\mathbf{n}=2246) \\
\end{array}$ & $\begin{array}{c}\text { Non-CYP2D6 } \\
\text { group } \\
(n=756) \\
\end{array}$ & \\
\hline $\begin{array}{c}\alpha \text {-Receptor } \\
\text { blockers }\end{array}$ & 6.11 & 6.17 & 6.15 & .99 \\
\hline ACE inhibitors & 43.68 & 43.2 & 43.69 & .97 \\
\hline $\begin{array}{l}\text { Angiotensin II } \\
\text { receptor } \\
\text { antagonist }\end{array}$ & 10.06 & 9.54 & 9.45 & .88 \\
\hline $\begin{array}{l}\text { Calcium channel } \\
\text { blockers }\end{array}$ & 20.69 & 20.58 & 20.65 & .99 \\
\hline Clopidogrel & 15.33 & 14.04 & 14.8 & .75 \\
\hline Diuretics & 32.92 & 31.07 & 33.33 & .54 \\
\hline Nitrates & 33.63 & 31.79 & 33.12 & .68 \\
\hline Statins & 52.62 & 52.36 & 52.63 & .99 \\
\hline Warfarin & 4.35 & 4.07 & 3.85 & .84 \\
\hline Year of surgery & & & & .84 \\
\hline 2001 & 18.28 & 18.58 & 17.51 & \\
\hline 2002 & 16.32 & 17.78 & 16.87 & \\
\hline 2003 & 12.96 & 12.81 & 13.43 & \\
\hline 2004 & 9.28 & 9.04 & 11.81 & \\
\hline 2005 & 9.76 & 9.65 & 9.29 & \\
\hline 2006 & 9.13 & 8.6 & 9.08 & \\
\hline 2007 & 8.95 & 7.2 & 8.4 & \\
\hline 2008 & 8.31 & 8.25 & 6.7 & \\
\hline 2009 & 7.03 & 8.1 & 6.92 & \\
\hline
\end{tabular}

Data presented as percentages. For method of propensity score adjustment, see the "Statistical Analysis" section in the "Methods" section. $B B, \beta$-Blocker; EuroSCORE, European System for Cardiac Operative Risk Evaluation score; $C O P D$, chronic obstructive pulmonary disease; $P V D$, peripheral vascular disease; $C V A$, cerebrovascular accident; $M I$, myocardial infarction; $A C E$, angiotensinconverting enzyme. *The definitions of these risk factors were determined from the definitions (Table E1) used by the EuroSCORE scoring system [Nashef SA, Roques F, Michel P, Gauducheau E, Lemeshow S, Salamon R. European system for cardiac operative risk evaluation (EuroSCORE). Eur J Cardiothorac Surg. 1999;16:9-13.] 